\title{
KRAUZ, Luis S. As musas: poesia e divindade na Grécia Arcaica. São Paulo: Editora da Universidade de São Paulo, 2007 - ISBN: 978-85- 314-1002-4
}

Resultado de extensa pesquisa de Luis S. Krausz a respeito do papel do culto às Musas e da poesia na Grécia Antiga, a recente publicação As musas: poesia e divindade na Grécia arcaica vem dividida em três capítulos bastante sugestivos: Invocação, Iniciação e Inspiração. Cada um deles é, por sua vez, dividido em três tópicos, totalizando nove, o número das musas, segundo Hesíodo.

Essa divisão produz um efeito estético considerável, uma vez que o próprio livro nos apresenta a hipótese segundo a qual havia, muito antigamente, apenas uma deusa patrona da poesia. Essa deusa possuiria três faces, que posteriormente se transformaram em três musas diferentes e, ainda mais posteriormente, cada face das três musas originais teria se transformado em uma musa independente, totalizando as nove de que nos fala Hesíodo.

Diga-se de passagem, ao que nos parece, por se tratar de poesia, nos moldes dos autores antigos, Krausz coaduna assunto e linguagem - basta notar a divisão metodológica da abordagem - sem descuidar do rigor científico necessário para que se confie nas informações fornecidas.

$\mathrm{Na}$ introdução, de forma propedêutica, apresentando ao leitor a forma grega de olhar o mundo, são arroladas as figuras essenciais para a feitura da obra poética, os aedos e rapsodos da Grécia arcaica.

O primeiro capítulo, Invocação, traz-nos principalmente a tradição homérica, em que a relação entre o aedo e as musas é expressa quase exclusivamente pelas invocações. Para explicar essa relação, o autor a princípio vai discutir o difícil conceito de "alma" entre os gregos. Seriam os mortais totalmente suscetíveis às influências divinas? Krausz nos prova que, apesar de para muitos teóricos os gregos acreditarem que sim, as teorias modernas apontam para certa autonomia humana. Embora os mortais sejam influenciáveis pelos deuses, possuem opinião e vontade próprias.

A seguir o livro nos apresentará as musas propriamente, mostrando primeiro como elas e os aedos são representados na Ilíada, e, depois, na Odisseia. Uma informação, atestada com exemplos, pelo autor e que seria interessante realçar é que, nas invocações, os aedos nunca pedem às musas a fluência ou beleza da canção, eles pleiteiam para si a verdade, os fatos. Esse tipo de invocação, é especialmente importante 
para interpretar a poesia homérica, na qual as musas são as portadoras da verdade dos fatos, em outros termos, trata-se de uma poesia na qual a verdade se faz palavra. Contudo, como é do conhecimento de todos, para Hesíodo, elas são capazes de contar mentiras semelhantes a verdades, quando querem. Essa divergência poética Krausz a resolve afirmando que em Homero as mentiras são consideradas os particulares dos mortais, enquanto a verdade pertence à esfera do divino, que doada aos poetas confere beleza à canção. Krausz considera importante também mostrar que, embora na poesia homérica a canção seja considerada um dom das musas, uma experiência religiosa, quase uma possessão semelhante à da Pítia, existem aedos que cantam utilizando apenas a própria experiência, sem influências divinas, como Aquiles entretendo a si mesmo com uma canção sobre a glória dos guerreiros.

No segundo capítulo, Iniciação, temos análises primeiro da poesia de Hesíodo, em seguida de Arquíloco e por fim de Álcman. Hesíodo, ao contrário de Homero, mostra a própria voz dentro da poesia e se mostra como autor de seus poemas. No entanto, em cada poema agradece às musas, e, em um deles, narra até mesmo como adquiriu seu dom. Iniciado pelas deusas no monte Hélicon, a partir desse momento, pôde utilizá-lo a seu bel-prazer, desde que se lembrasse constantemente de agradecer às deusas. Arquíloco, escrevendo sobre a esfera da própria vida privada, na opinião do helenista, não deixa marcas da influência das musas em sua poesia. Não as invoca, e, uma vez apenas, dá a entender que elas lhe ensinaram a arte poética. Sobre a iniciação do poeta soldado, outras fontes informam: as musas lhe teriam oferecido uma lira em troca de uma vaca. Dessa forma, o presente das musas para o filho de Tellis não foi a voz, o dom poético oferecido a Hesíodo, mas o próprio instrumento musical. Arquíloco teria, mais tarde, aprendido a tocá-lo, sendo o único autor de seus poemas, sem qualquer influência divina. Alcman, afirma Krausz, é um caso diferente e mais difícil de analisar. Por ser poeta profissional e só escrever, até onde se sabe, poesia pública para as datas cívicas de Esparta, sua poesia vem marcada por funções didática, pedagógica e cívica bem definidas. Torna-se difícil separar o "eu" poeta do "eu” coral, o que acaba por se constituir traço distintivo do espartano e não simples cópia da tradição. Em sua poesia vemos invocações semelhantes às homéricas, mas elas estão em situações tais que só é possível pensar em recriação. Vemos em trechos mais originais afirmações da própria autoria, como "cantarei”, e não "canta, Musa". Assim, Álcman, dos três, parece ser o poeta mais próximo da profanação da canção, já apontando para um período em que o 


\section{nuntius antiquus}

aedo é considerado o único autor do poema, sem a influência da musa.

No terceiro capítulo, Inspiração, temos diversas informações literárias e arqueológicas a respeito do culto às musas: elas eram cultuadas em Delfos muito antes de Apolo, quando o templo ali situado pertencia a Gaia. Krausz mostra que o culto às musas é muito antigo, sendo vinculado ao da Grande Deusa, assim como ao das ninfas. Para ele, o fato de haver muitas variações dialetais para o termo "mô̂sa", por exemplo, aponta para certa antiguidade da palavra na língua grega.

Finalmente, podemos concluir que, em seu livro, Krausz cria uma excelente iniciação ao estudo das musas, inclusive a termos complexos de difícil entendimento. Ele produz uma visão sobre uma extensa parte da poesia grega arcaica, analisando vários autores e consultando diversos teóricos. No entanto, apesar de sua publicação ser recente, percebe-se uma defasagem na bibliografia. Não se pode dizer que faltem argumentos ou comprovações no texto, mas na passagem em que Krausz compara o culto às musas ao culto às ninfas teria sido interessante detalhar também o campo semântico que cerca estas divindades nos modos dos capítulos anteriores. Sutilezas que Jennifer Larson em seu Greek nymphs: myth, cult, lore ${ }^{1}$ mostrará à luz de evidências arqueológicas para o caso de termos como "ninfolepto" e "ninfolepsia".

Disponível não apenas para estudiosos como para leigos, esta obra pode acarretar, pela erudição, algumas dificuldades (termos em grego sem tradução e referências sem a citação por extenso). Merece louvor a objetividade científica. Apesar do excesso de síntese em algumas passagens, o livro As musas: poesia e divindade na Grécia Arcaica é excelente introdução ao estudo do tema, contendo, além de informações pertinentes, várias referências a outras fontes, constituindo um material de ótima qualidade para um ponto de partida seguro e embasado para qualquer pessoa interessada.

Ana Cristina Fonseca

Universidade Federal de Minas Gerais/ I.C. FAPEMIG anacris_f14@hotmail.com

\footnotetext{
${ }^{1}$ LARSON, J. Greek nymphs: myth, cult, lore. Oxford/ New York: Oxford University Press, 2001, p. 1119.
} 